\title{
Mecmuâ-i Sâz ü Söz’de Yer Alan Dini Musiki Eserleri Üzerine Bir İnceleme*
}

\author{
An Analysis on Religious Musical Works in Mecmuâ-i Sâz ü Söz \\ Ubeydullah İșler \\ Arş. Gör., Çanakkale Onsekiz Mart Üniversitesi, İlahiyat Fakültesi, İslam Tarihi ve Sanatları Bölümü \\ email: ubeydullahisler@,comu.edu.tr (DORCID ID: https://orcid.org/0000-0002-0040-7893
}

\section{Ömer Can Satır}

Doç. Dr., Hitit Üniversitesi, Güzel Sanatlar Tasarım ve Mimarlık Fakültesi, Müzik Bölümü email: omercansatir@hitit.edu.tr (DORCID ID: https://orcid.org/0000-0001-8568-5018

* Bu araştırma “Mecmuâ-i Sâz ü Söz'de Yer Alan Dini Eserlerin İncelenmesi” başlıklı yüksek lisans tezinden türetilmiştir. $\checkmark$ Torhentronticatesearchers
gerektirmemektedir.

Atıf (APA 7)/To cite this article

İşler, U., \& Satır, Ö. C. (2021). Mecmuâ-i Sâz ü Söz'de yer alan dini musiki eserleri üzerine bir inceleme. Atatürk Üniversitesi Güzel Sanatlar Enstitüsü Dergisi, 27(47), 362-376. https://doi.org/10.35247/ataunigsed.938182

Makale Gönderim Tarihi/Received: 17/05/2021

Makale Kabul Tarihi/Accepted: 24/08/2021

Makale Yayın Tarihi/Published: 28/10/202

Research Article / Araștırma Makalesi

$\ddot{O} z$

Yapılan bu çalıșmanın odak noktasını 17'nci yüzyılın önemli eserlerinden Mecmuâ-i Sâz ü Söz'de yer alan dini musiki eserleri oluşturmaktadır. İlahi, tesbih, tevhid ve ayin-i şerif gibi Türk din musikisinin önde gelen 34 repertuvar bileșeni mecmua içindeki sayısal dağılım, nota yazısında kullanılan işaretler, makam, usul ve form yapısı başta olmak üzere güfte dinamikleri üzerinden analiz edilmiştir. Yapılan değerlendirmeler 1şı̆̆ında dini türlerin mecmua içinde dokuz farklı fasıl içinde tanzim edildiği; bilhassa ilahi ve tesbihlerin șemsiye bir başlık olarak kullanıldığı; tevhid türünün anlamına uygun bir örnekle temsil edildiği; ayin-i şerif' in ise günümüzdeki ayin formunun üçüncü bölümünden ibaret olduğu tespit edilmiştir. Ayrıca bu eserlerde anahtar ve usul göstergeleri ile ses değiştirici işaretler bulunmaktadır. Yine röpriz, puandorg, uzatma ve deyim bağı gibi notalama ișaretlerini görmek mümkündür. Dini eserlerin ezgi organizasyonu on beş farklı makam içinde yer alırken Hüseyni ve Neva makamları nicel olarak öne çıkmaktadır. Buna karşın günümüzün dini musiki repertuvarında oldukça sı kullanılan Uşşak ve Segâh makamlarının temsil oranı oldukça düșüktür. Zaman organizasyonu ise beş farklı usul üzerinden gerçekleşirken burada Düyek usulü öndedir. Usulü belirlenemeyen eserlerin varlığı ise dikkat çekicidir. Eserler form açısından değerlendirildiğinde ilahi, tevhid ve ayin şerif'in tesbihlere nazaran sınırlı bir müzikal ifadeye sahip olduğu, biçim yapısı açısından tesbihlerin diğer türlerden ayrıldığı görülmektedir. Güfte bakımından aruzlu yapının hâkimiyeti öne çıkarken dini eserlerin anlam evrenini ağırlıklı olarak gazel, murabba ve koşma nazım şekilleri inşa etmektedir.

Anahtar kelimeler: Mecmuâ-i Sâz ü Söz, Ali Ufki, Türk Din Musikisi, Osmanl1/Türk Müziği

\begin{abstract}
The focus of this work is on the religious music works in Mecmuâ-i Sâz ü Söz, one of the important works of the 17th century. The 34 leading repertoire components of Turkish religious music such as ilahi (hymn), tesbih, tevhid, and ayin-i şerif were analyzed through the dynamics of the lyrics, especially the numerical distribution in the work, the signs used in the musical score writing, maqam, usul (rhythmic patterns) and musical form structure. In the light of the evaluations made, religious types are arranged in nine different chapters in Mecmuâi Sâz ü Söz; especially an umbrella headgear where ilahi (hymn) and tesbih was used; tevhid is represented by an example that matches its meaning; It was determined that the ayin-i şerif consists of the third part of the present-day ritual form. In addition, these works contain the clef and the usul indicators and accidental signs. It is also possible to see notational signs such as repeat, fermata, slur, and extension tie. While the melody organization of religious works takes place in fifteen different maqams, Hüseyni and Neva maqams stand out quantitatively. On the other hand, the representation rate of the Ușşak and Segâh maqams, which are frequently used in today's religious music repertoire, is very low. While the organization of time takes place over five different usul, Düyek is ahead here. The existence of works whose usul cannot be determined is striking. When the works are evaluated in terms of musical form, it is seen that the ilahi, tevhid, and ayin-i serif have a limited musical expression compared to the tesbihs, and the tesbihs differ from other genres in terms of their form structure. While the dominance of the structure with aruz wezni stands out in terms of lyrics, the semantic universe of religious works is mainly constructed by the poetic forms of gazel, murabba, and kosma.
\end{abstract}

Keywords: Mecmuâ-i Sâz ü Söz, Ali Ufki, Turkish Religious Music, Ottoman/Turkish Music

\section{Giriş}

Mecmuâ-i Sâz ü Söz, Ali Ufki tarafından 17'nci yüzyılda kaleme alınmış ilk repertuvar kitabı olarak karşımıza çıkmaktadır. Kitap, içeriğinde farklı tür ve repertuvar bileşenlerinden oluşan 22 fasıl çatısı altında toplam 544 adet musiki eseri barındırmaktadır. Eseri Türk müzik tarihi açısından önemli kılan husus ise Osmanlı döneminin müzikal birikimini Avrupa notası ile birlikte elimize ulaştıran ilk eser olmasından kaynaklanmaktadır. Bir başka deyişle folklorik türlerden dini musiki eserlerine çalgısal formlardan klasik Türk müziğinin ilk sözlü eserlerine kadar geniş bir yelpazede elimize notaları ile ulaşan en eski eserleri Mecmuâ-i Sâz ü Söz adlı yazmanın içerisinde görmek mümkündür. Yüzlerce repertuvar bileşeniyle Topkapı Sarayının sesini günümüze ulaştıran bu kaynağın 
bir başka önemi ise içinde Türk müzik tarihinin ilk dini musiki eserlerini barındırıyor olmasıdır. Bu doğrultuda kaleme alınan makalenin amacı, 17 'nci yüzyılda Osmanlı'daki musiki anlayışını Ali Ufki bağlamında genel hatları ile değerlendirmek ve onun kaleminden notaları ile birlikte günümüze ulaşan Türk din musikisinin ilk eserlerini incelemektir. Ali Ufki ve Mecmuâ-i Sâz ü Söz özelindeki bu çalışmanın kapsamını ise eser içerisinde tespit edilen dini musiki örnekleri oluşturacaktır.

Mecmuâ-i Sâz ü Söz pratik anlamda dönemin musiki eserlerini günümüze ulaştırmasının yanı sıra teorik olarak da dönemin makam anlayışı, icra geleneği ve usul anlayışı hususunda müzikolojik açıdan oldukça güçlü veriler sunmaktadır. Bu doğrultudaki yapılan incelemeler neticesinde ihtiva ettiği toplam repertuvar bileşeni içinde 34 eserin dini nitelikli olduğu tespit edilmiştir. Tür bağlamında değerlendirildiğinde ise 14 eserin ilahi, 18 eserin tesbih ve birer eserin tevhid ve ayin-i şerif olarak nitelendirildiği görülmektedir. Bu noktada şunu belirtmek gerekir ki kavramsal olarak tevhid, tesbih ve ayin gibi kelimelerin 17 'nci yüzyıldan önce kullanıldığı bilinse de ilahi kelimesinin bir edebiyat ve musiki kavramı olarak kullanılması bu dönemden öteye geçmemektedir. Bu çerçevede Ali Ufki Bey'in ilahi kelimesini teknik anlamda kullanan ilklerden biri olduğu düşünülebilir. Söz konusu dini nitelikli eserlere dair bulgulara geçmeden önce başta Ali Ufki olmak üzere Mecmuâ-i Sâz ü Söz hakkında birkaç söz söylemek yerinde olacaktır.

\subsection{Yüzyılda Osmanlı’da Musiki ve Ali Ufki}

Dini, askeri ve klasik türde hayat bulan ve toplumsal alanların hemen hemen hepsinde kullanılmış olan Osmanlı musiki sanatı, Türk musikisinin hemen hemen beş asırlık bir bölümünü oluşturmaktadır. Türklerde eskiden beri süre gelen ve gelenekselleşen bir tutum, askeri ve idari yönetim dışında, toplumu fikir ve sanat anlamında da geliştiren bir yönetim anlayışı Osmanlı İmparatorluğu'nda da kendini göstermektedir. Bunun en açık örneği ise İmparatorluk dâhilinde üst düzey fikir ve sanat adamlarını toplayan ve bu kişileri maddi-manevi destekleyen herhangi bir ayrımcılık gözetmeksizin muhafaza eden Osmanlı padişahlarıdır (Tanrıkorur, 2003, s. 13-18). 17'nci yüzyılda duraklama hemen hemen her alanda kendini gösterse de güzel sanatlar alanında bu durum tam tersidir. Bilhassa bu dönemde Türk musikisi büyük bir gelişim göstermiştir. Çağın önde gelen padişahları musiki sanatının gelişimine hem bu sanatla ilgilenerek hem de musikişinasları himaye ederek önemli katkılarda bulunmuşlardır (Öztuna, 1987, s. 82-83). Behar (1991)'ın Ali Ufki'nin İstanbul'a gelişi ve saray serüveni ile ilgili tahminde bulunduğu tarihler esas alındığında onun IV. Murad döneminden itibaren Osmanlı'daki musiki hayatını tecrübe ettiğini söylemek mümkündür (s. 17-18).

Bu noktada Osmanlı'da musikiyi yalnızca saray ve çevresinde aramak yanlış olacaktır. Nitekim 1728-30 yılları arasında Şeyhü'l-İslam Esad Efendi tarafından kaleme alınan Atrâbu'l- Âsâr fi Tezkireti Urefâi'l- Edvâr adlı Osmanlı döneminin tek musikişinas tezkiresi incelendiğinde meslek ve faaliyetleri belirtilen musikişinasların çok azının bir şekilde sarayda görevlendirildiği anlaşılmaktadır. Aralarında esnaf, din adamı, bürokrat gibi farklı mesleki nitelikte birçok kişinin bulunması musikinin toplum içerisindeki karşılığını göstermesi açısından önemlidir (Behar, 2015, s. 22). Her ne kadar tezkire dönemin ilk yarısında yazılmış olsa da tüm bir 17'nci yüzyılı kapsar nitelikte olabileceği öngörülmektedir.

Osmanlıda musiki iklimi denildiğinde kuşkusuz en önemli hususların başında müziğin aktarım ve intikal süreci gelmektedir. Ayangil (2014)'in de vurguladığı gibi dini musikinin eğitim süreci tekke ve Mevlevihanelerde, ladini musiki eğitimi ise Enderun içindeki meşkhanelerde alanında kendisini ispatlamış yerli, mühtedi ve devşirme musikişinaslarca yürütülmektedir (s. 470). Yine aktarım ve intikalin ev, cami gibi özel ve genel alanlarda saray himayesi ve teşviki dışında da bağımsız olarak devam etmiştir (Behar, 2015, s. 21). Keza Uzunçarşılı (1977) Enderun'da musiki eğitimi için büyüklü küçüklü odalar tahsil edilerek devşirme olan çocuklar arasından kabiliyetli olanların diğer saraylardan alınarak bu odalarda eğitime tabi tutulduğunu belirtmektedir (s. 86-87). Ayrıca Ali Ufki anılarını kaleme aldığı Saray-1 Enderun (2013) adlı eserinde Uzunçarşılı'nın üzerinde durduğu odalar ve eğitim sistemi hakkında bilgiler vermektedir. Yine muhtelif kaynaklar Osmanlı'daki musiki eğitiminin Enderun Mektebi, Mehterhane, Mevlevihaneler ve Muzıka-i Hümayun gibi yapılar aracılığıyla Tanzimat dönemine kadar kurumsal olarak devam ettiğini göstermektedir (Özden, 2020, s. 118).

$\mathrm{Bu}$ yapılardaki musiki aktarım ve intikalinin temelinde meşk sistemi bulunmaktadır. Osmanlı'daki musiki eğitiminin mihenk taşını oluşturan bu sistem hoca merkezli olup talebe uzun yıllar öğrenime devam etmektedir. Mutlak itaat ve terbiye esaslarını temel alan bu eğitim anlayışında talebenin mutlak bir disiplin içerisinde öğrenimine devam etmesi gerekmektedir. Zira bu ortamlarda yapılan basit hatalar dersten ve eğitim sürecinden ihraca kadar varan örnekler ihtiva etmektedir (Özden, 2020, s. 40-41). Söz konusu bu ortamlarda müziğin aktarımı şifahi kültüre dayanırken mecmua ve cönkler aracılığıyla yalnızca güftenin kaleme alınması doğal karşılanmaktadır. Ancak müziğin notayla kayda alınması ve icrası hiç de makbul bir durum değildir. Marifet tüm bir repertuvarı hıfzetmek, hafızadan söylemektir. Bu açıdan Ali Ufki ve eseri Mecmuâ-i Sâz ü Söz dönemin müzik anlayışını sözlü kültürden yazılı kültüre geçirerek müziğin aktarım ve intikalini farklı bir boyuta taşımıştır. Bu anlamda Ali Ufki biyografisine kısaca değinmek yerinde olacaktır. 
Avrupalı kaynaklarda Albert Bobowski veya Bobovius olarak anılmakla birlikte asıl adı Wojciech Bobowski olan Ali Ufki, günümüz Ukrayna sınırları içerisinde bulunan Lwow/Lviv şehrinde doğmuştur. Asilzade bir aileden geldiği iddia edilmekle birlikte Polonya ve tüm Batılı kaynaklar doğum tarihini 1610 olarak vermektedir (Behar, 2017, s. 17-18). İsimlendirilmesi hakkında farklılıkların bulunduğunu belirten Karakaya (2010) vaftiz adının Wojciech Bobovius olduğunu, bu durumun Latince eserlere geçtiğinde Albertus Bobovius'a dönüştüğünü ve bu isimlendirmenin de milletlere göre farklılaştığını söylemektedir (s. 9). Türkçede Hali Beigh, Hali Beg, Ali Bey, Hulis Bey gibi isimlere rastlanırken bazı Batılı kaynaklarda Bobonius, Bohonius, Bobrowski, Bozonius, Robovius olarak zikredilmektedir. Bu isimlendirmedeki farklılığın temel sebebi dini-kültürel birtakım uygulamalar ve telaffuz farklılığıdır. Bertilen tüm bu isim sarmalında bahsi geçen kişinin Ali Ufki Bey olduğu bilinmelidir. İsimlendirilmesi ile ilgili diğer bir durumu ise onun mahlası oluşturmaktadır. Üngör (1987) kaleme aldığ makalesinde Muammer Uludemir'in "Ufki mi? Ufuki mi?" olduğuna dair bir seminer verdiğini ve bu seminer sonucunda "Ufuki" olarak kabul edildiğini ancak Prof. Dr. Halil İbrahim Şenel'in bu hususu delillendirerek "Ufki" olduğunu kanıtladığını belirtmektedir (s. 27).

Polonya kaynaklarına göre Ali Ufki Lehistan'a birçok kez sefer düzenleyen Kırım Tatarları tarafından esir alınarak İstanbul'a getirilmiştir (Behar, 2017, s. 18). Bu seferlerden en önemlilerinden biri 1633 yılında Hotin-Kamaniçe bölgeleri arasında yapılan savaştır ki bölge Ali Ufki'nin doğduğu Lviv şehrine yakınlığı ile bilinmektedir. Nâima’nın (ö. 1716) ifadesiyle bu savaşa Kantemiroğulları Orak Mirza ve Hüseyin Mirza, Nogay ve gayri Tatarlar katılmıştır. Bu noktada anlaşılan "Kırım Tatarları tarafından esir alındığı iddiasının” bu savaşa katılan etnik yapılarla ilgili olması ihtimal dâhilindedir. Yukarıda belirtilen 1633 tarihi esas alındığında Ali Ufki'nin saraya giriş tarihini 1633 sonları veya 1634 yılı olarak tahminde bulunmak mümkündür (Behar, 1991, s. 17-18). Belgelenemeyen bir rivayette onun uzun süre sarayda bulunduğundan daha sonra Misır'a sürüldüğünden ve buradaki hizmetinden dolayı serbest bırakıldığından söz edilmektedir (Behar, 2017, s. 18). Ayrıca bazı Avrupalı yazarlar Ali Ufki'nin sarayda geçen ilk döneminin 19 yıl sürdüğünü kesin bir ifade ile yazmaktadır (Karakaya, 2010, s. 10). 1651 yılında Kösem Sultan'ın IV. Mehmed'i zehirleme girişimini tanık olarak anlatması onun bu tarihlerde sarayda olduğunun göstergesidir. Bu bilgiden hareketle de onun sarayda 19 yıl geçirdiği bilgisi ile en erken saraya girişini 1632 yılı olarak belirlemek mümkündür. Gerçek şudur ki; onun hem esaret hayatı hem İstanbul'a gelmeden önceki hayatı ve sonrası hakkında ayrıntılı bilgi bulunmamaktadır. Yazdıkları eserler temel alındığında onun hayatında karanlık kalan bölümleri aydınlatmak pek mümkün görünmemektedir (Behar, 1990, s. 10-12).

Topkapı Sarayına ilk olarak ne sıfatla alındığına dair herhangi bir belge bulunamasa da musiki ile ilgilendiği ve bu sanattaki üstün meziyetlerinden dolayı çeşitli unvanlarda görev aldığı kendi kaleme aldığı yazılardan anlaşılmaktadır. Bu yazılarda padişaha musiki alanında hizmet ettiği, üstün yeteneğinden dolayı erbaşı veya korobaşı unvanına layık görüldüğünden bahsedilmektedir (Yerasimos ve Berthier, 2012, s. 77). Tespit edilen diğer bir görev ise Divan-1 Hümayun tercümanlığıdır. Cengiz Orhonlu, 1668 yılında Divan tercümanlı̆̆ı unvanı ile ödeme yapıldığına dair evrakı Osmanlı arşivlerinden teşhir etmiştir (Elçin, 2000, s. XIII). Evrak incelendiğinde Ali Ufki'nin sürekli bir tercüme vazifesinde bulunmadığı, belirtilen zamanlarda kısa süreli görevlendirildiği ve günlüğü 5 akçadan toplam 315 akça ödeme yapıldığı anlaşılmaktadır. Ayrıca kaynaklarda 13 kadar dil bildiğine dair verilerin olması tercümanlık görevinde bulunma ihtimalini güçlendirmektedir (Behar, 1990, s. 18).

Ölümü ile ilgili yer ve tarih hususları net olmamakla birlikte birtakım ihtimaller ortalama bir tarihsel değerlendirme yapmaya yardımcı olmaktadır. Bu ihtimallerden Cornelio Magni'nin Saray-1 Enderun adlı eserin İtalyanca baskısında 14 Ekim 1672 tarihli bir sunuş yazmış olması dikkat çekmektedir. Ancak bu onun yaşadığına veya öldüğüne dair bir bilgi vermemektedir (Behar, 1990, s. 41). Yine aynı yazar 1679 yılında Parma'da basılan Saray1 Enderun'u da kapsayan İstanbul Seyahatnamesinin önsözünde Ali Ufki’nin Müslüman olarak ölmüş olduğuna değinmektedir (Behar, 2017, s. 51). Magni’nin verdiği veriler göz önüne alındığında netlik olmasa da 1672-1679 gibi bir tarihsel daraltma yapmak mümkündür. Ölümü ile ilgili tarihsel daraltma hususunda Fransız şarkiyatçı Antonie Galland, seyyah Jacop Spon'a 10 Mayıs 1677'de yazdığ 1 bir mektupta Ali Ufki Bey'den ölmüş biri olarak söz etmesi 1677 tarihini güçlendirmektedir (Behar, 1990, s. 42). 1670-1673 arasında çok ayrıntılı bir günlük tutan Galland'ın İstanbul'da sefaret görevlisi olarak bulunduğu bilinmekle birlikte Ali Ufki Bey'e yer vermemesi de manidardır. Galland'ın tarihsel süreci esas alındığında ise bu tarih biraz daha daralmakta ve 1673-1677 tarihleri güçlenmektedir. Ancak Batılı kaynaklar 1675 yılını esas almaktadır. Galland ve Magni'nin tarihsel verileri değerlendirildiğinde bu tarihi kabul etmek mümkün gözükmektedir (Behar, 1990, s. 42). Belirtilen tüm tarihsel aralıkta ölmüş olma ihtimali bulunmakla birlikte Cahit Öztelli kaleme aldığ 1 bir yazıda onun bir şiirini delil göstererek 1676'da hayatta olduğunu ileri sürmektedir (Behar, 2017, s. 51). Ancak Oransay (1976) bu konuda bir makale yazarak söz konusu iddiayı çürütmektedir (s. 224). Tüm bu tarihsel süreçle ilgili ölmüş olma veya yaşıyor olma ihtimali mümkün gözükmektedir. Zira hiçbir tarih kesinlik ifade etmemektedir. Tüm bu tarihleri kapsayan 1673-1677 tarihleri arasında öldüğünü söylemek mümkündür. Yani yaşadığı dönem hakkında çıkarılabilecek en makul sonuç 1610-1677 yılları aralığıdır. Ölüm yeri ile ilgili de Oransay’dan (1976) yola çıkarak Osmanlı toprakları içerisinde öldüğü söylenebilir (s. 224). 


\subsection{Ali Ufki’nin Musikişinas Yönü ve Mecmuâ-i Sâz ü Söz}

Hayatı incelendiğinde Ali Ufki'nin hiç şüphesiz en maharetli yönü musikişinas kişiliğidir. Nitekim kendisi 17'nci yüzyılın musiki hayatını günümüze ulaştıran belki de en önemli kişidir. Musikiye dair bilinen üç elyazması bulunmaktadır. Bunlardan ilki Mecmuâ-i Sâz ü Söz, ikincisi Bibliotéque Nationale de France’taki [Turc 292] katalog numaralı yazma üçüncüsü ise Mezmurlardır. Bu üç eserden zamanının musiki atmosferini günümüze aktaran en önemlisi Mecmuâ-i Sâz ü Söz'dür. Bu eser [Sloane 3114] katalog numarası ve Turkish Songs adı altında Londra'daki British Museum envanterine kayıtlıdır. Mecmuanın kapağında belirtildiği gibi Ali Ufki bir santuridir. Bunun yanı sıra IV. Mehmed'in sazendeliğini yapmıștır. Mecmuâ-i Sâz ü Söz'de kendisine ait beste ve güfteler bulunmaktadır. Yerasimos ve Berthier (2012) onun Batı müziğindeki üstün kabiliyeti ile Topkapı sarayında hanendelik ve sazendelik yaptığından söz ederken, üst düzey müzikal donanımı sayesinde musiki hocalığ1 görevine layık görüldüğü ve Avrupa nota yazısı bilgisiyle diğer musikişinaslardan ayrıldığı; İstanbul'a gelmeden önce İtalya'da aldığı müzik eğitimi sayesinde öğrendiği eserleri notaya aktarma kabiliyeti kazanmasıyla Topkap1 Sarayındaki diğer musikişinaslarca hayretle izlendiği ve bu sayede korobaşı unvanına layık görüldüğü; ayrıca Ali Ufki’nin musiki ve edebi türler üzerine derinlikli bilgi sahibi olmakla birlikte Osmanlı ve Batı çalgıları arasında mukayese yapacak kadar donanımlı müzik bilgisine sahip olduğundan bahsetmektedir (s. 12-77). Behar'1n (1990) ve (2008) yaptığı çalışmalardan da anlaşılacağı üzere makam müziğinin önemli bileşenlerinden usul konusu hakkında bilgi sahibi olduğu görülmektedir.

Yukarıda da değinildiği gibi Mecmuâ-i Sâz ü Söz Ali Ufki’nin en önemli musiki eseridir ve içinde Avrupa notasıyla yazılmış beş yüzden fazla saz ve söz eseri barındırmaktadır. Bu esere ilk dikkat çeken Avrupalı şarkiyatçılardır. 23 Eylül- 16 Ekim 1675 tarihleri arasında İstanbul'da bulunan İngiliz seyyah Jacop Spon 1678 yılında yayınladığı seyahatnamesinde Ali Ufki'nin kaleme aldığı bu eserden söz etmiştir. Ülkemizdeki farkındalığı 20'nci yüzyılın ikinci yarısına tekabül etmektedir. İlk kez Çağatay Uluçay 1948 yılında "Mecmua-yı Saz u Söz" makalesiyle konuya dikkat çekmiştir (Behar, 1990). Elçin (2000)'e göre eserin 9-b yaprağındaki ilk şiirin başlığ "Hazâ Mecmuâ-i Sâz ü Söz" şeklindedir ve mecmua beste, nota ve şiirlerden mütevellittir. (13x19.5) santimetre ebadında ve 184 yapraklı olan eser biri hat olmak üzere iki farklı yazı stili ile kaleme alınmıştır. Son olarak söz konusu mecmua hakkında Oransay (1972) Ali Ufki ve Dini Türk Musikisi başlı̆̆ ile doçentlik tezi, Cevher (1995) Ali Ufki Bey ve Haza Mecmua-i Saz ü Söz (Transkripsiyon-İnceleme) başlı̆̆ı ile doktora tezi kaleme alarak Ali Ufki ve Mecmuâ-i Sâz ü Söz araştırmalarına katkı sağlamıştır.

\section{Yöntem}

Araştırma betimsel modele dayalı nitel bir araştırmadır. Bu bağlamda Mecmuâ-i Sâz ü Söz'de (MSS) yer alan dini nitelikli eserler fasıl, tür, makam, usul, form ve güfte yapısı ile Ali Ufki'nin kaleme aldığı notaların üzerinde bulunan müziğe dair gösterge ve işaretler açısından detaylı bir irdelemeye tabi tutulmuştur. Bu bağlamda ilk olarak MSS'deki dini nitelikli eserler fasıl bazında ayrıştırılarak hangi türün Ali Ufki'nin tasnif ettiği hangi fasıl içinde yer aldığı bilgisi sayısal dağılım bazında belirlenmiştir. Akabinde Ali Ufki bu eserleri notaya alırken hangi gösterge ve işaretleri kullandığı sorusuna yanıt aranmış, başta anahtar simgesi olmak üzere dini nitelikli eserlerde kullanılan usul ve arıza işareti ayrıntılı olarak tanımlanmıştır. Bu başlıkta altında yapılan makam ve usul tespitinde ise başta Kantemiroğlu edvarı olmak üzere 17'nci yüzyıl ve öncesinin edvar kaynaklarından yararlanılmıştır. Müzik analizi bağlamında MSS'deki dini nitelikli türler günümüzün form anlayışı çerçevesinde ele alınmış olup eserlerin bağlı olduğu biçimsel yapı cümle ve bölüm cinsinden belirlenmiştir. Son olarak eserlerin güfte yapısı anlam evreni göz önüne alınmak suretiyle edebi tür, nazım ve vezin yapısı üzerinden tasnif edilmiştir.

\section{Bulgular}

Tablo 1

MSS'de Fasıllar İçinde Yer Alan Dini Eserlerin Sayısal Dă̆ılımı

\begin{tabular}{lcccc}
\hline Fasıl & İlahi & Tesbih & Tevhid & Ayin-i Şerif \\
\hline Hüseyni & 1 & - & - & - \\
Muhayyer & 2 & - & - & 1 \\
Neva & - & 3 & - & - \\
Acem & - & 4 & - & - \\
Sabâ & - & 2 & 1 & - \\
Rast & 2 & 2 & - & - \\
Eviç & 2 & 1 & - & - \\
Aşiran Buselik & 3 & - & - & - \\
Hisar & 4 & 6 & 1 & 1 \\
Toplam & 14 & 18 & & \\
\hline
\end{tabular}

Tablo 1'de görüldüğü gibi MSS'de ilahi, tesbih, tevhid ve ayin-i şerif' ten oluşan dini musiki örnekleri bulunmakla birlikte bu türlerin dokuz farklı fasıl içinde tanzim edildiği tespit edilmiştir. Ancak bu türler edebi bağlamda değerlendirildiğinde bazı eserlerin bağlı olduğu türün karakteristik niteliğini yansıtmadığı anlaşılmaktadır. Bu durum MSS'deki ilahi ve tesbih türlerinin anlam evreni açısından şemsiye bir başlık olarak kullanıldığını ortaya 
koymaktadır. Tablodaki her bir türe kısaca değinmek gerekirse ilahi türünün günümüzde olduğu gibi dini içerikli güftelerin bestelenmesi ile oluştuğu söylenebilir. Cevher (2003)'in de vurguladığı gibi ilahilerin basit ezgilerden oluşmadığı ve girift bir müzikal yapıda oldukları (s. 50); Tablo 1'de görüldüğü üzere 14 eserin ilahi başlığı çatısı altında nitelendiği; Hüseyni, Muhayyer, Rast, Eviç, Aşiran Buselik ve Hisar fasılları içinde yer aldığı anlaşılmaktadır. Tesbihlerde ise müzikal örgü ve anlatımın ilahilere göre daha yoğun olması dikkat çekmektedir. Yine tabloda görüldüğü üzere MSS'de 18 örneği bulunmaktadır. Tesbih çatısı altında yer alan eserler Neva, Acem, Saba, Rast, Eviç ve Hisar fasıllarında bulunmaktadır. MSS'de müstakil bir tür başlığı altında yer alan ve tek bir örneği bulunan tevhid ise Rast faslı içindedir ve günümüzdeki tevhid türü ile yakın benzerlik göstermektedir. Son olarak MSS'de tek bir örneği bulunan ve Muhayyer faslı içinde yer alan ayin-i şerif ise tekke musikisinin en önde gelen formudur. MSS'de yer alan ayin-i şerif örneği de Mevlevi ayinlerinin hemen hepsinde yer alan ve ayinlerin üçüncü hanesini oluşturan bölüme tekabül etmektedir.

Tablo 2

MSS'de Kullanılan Anahtar, Usul ve Arıza İşaretleri

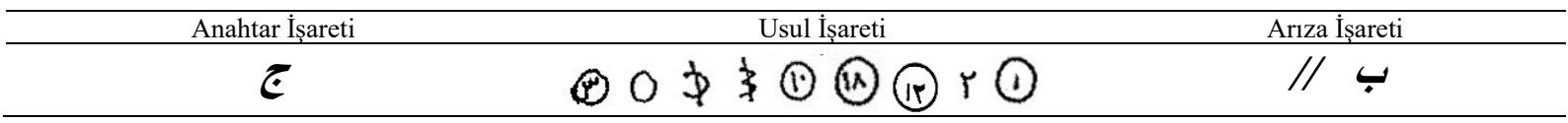

Tablo 2'de görüldüğü üzere MSS'deki dini eserlerde anahtar, usul ve ses değiştirmeye yönelik birtakım işaret kullanılmıştır. Buna göre ilahi ve tesbih türlerinde cim harfi ile (ج) sembolize edilen bir do anahtarı mevcuttur. Ali Ufki MSS'de do ve sol anahtarlarını kullanırken birinci, ikinci ve üçüncü çizgi üzerinde üç tip do anahtarı kaleme almıştır. Dini musiki eserlerinde ise ekseriyetle birinci çizgi do anahtarı üzerinden bir nota yazımı gerçekleştirmekle birlikte yalnızca bir eserde (MSS 317-2) üçüncü çizgi do anahtarı kullanmıştır. Tesbih ve ilahi dışında kalan tevhid ve ayin-i şerif ise anahtarsız olarak notaya alınmıştır.

MSS'de 14 ilahinden sadece dördünde ( MSS 85-2, 233-2, 247-2, 248-1) usul işareti kullanırken bu göstergeler dört farklı şekilde karşımıza çıkmaktadır. Bunlar semai usulüne denk gelen göstergesi ile düyek usulüne tekabül eden $\mathrm{O}, \$$ işaretleri ve devr-i revan usulünü karşılayan 3 işaretidir. Yine 18 tesbihten on ikisinde ( MSS 123-2, 123-3, 170-2, 171-1,171-3, 186-1, 233-1, 235, 315-1, 315-2, 316-1, 317-1) usul göstergesi mevcutken bu işaretler yedi farklı şekilde bulunmaktadır. Bunlar düyek usulüne tekabül eden O, \$, r, (1) işaretleri ile nim sakil usulüne denk gelen (i) işareti ve belirli bir usul göstergesine karşılık gelmeyen (1) ve (৫) işaretleridir. Sadece birer örneği bulunan tevhid ve ayin-i şerif’te de usul işaretleri bulunmaktadır. Tevhid örneğinde semai usulünü andıran işareti yer alırken ayin-i şerif' te düyek usulüne ait olan $\not$ işareti bulunmaktadır.

Ses değiş̧tirici işareti olarak ilahilerde dört eserde ( MSS 300-2, 302-2, 311-1, 315-3) bemol işlevi gören (ب) harfi yer alırken tesbihlerin dördünde ( MSS 170-2, 171-1, 171-2, 171-3) yine bu harf şeklini görmek mümkündür. Ayrıca diyez işlevi gören // çift eğik çizginin de varlığı dikkat çekidir. Ayrıca röpriz (II:), puandorg $(\mathcal{U})$, uzatma ve deyim bağı $\multimap$ gibi notalama işaretlerini diğer repertuvar bileşenleriyle birlikte Ali Ufki'nin dini musiki eserlerinde görmek mümkündür.

Tablo 3

MSS'deki Dini Eserlerin Makamsal Dağılımı

\begin{tabular}{lcccc}
\hline Makam & İlahi & Tesbih & Tevhid & - \\
\hline Acem & - & 3 & - & - \\
Acem Aşiran & 1 & 1 & - & - \\
Aşiran Buselik & 1 & - & - & - \\
Buselik & - & 1 & - & - \\
Eviç & 2 & - & - & - \\
Hüseyni & 4 & 1 & - & - \\
Irak & - & 1 & - & - \\
Muhayyer & 2 & 1 & - & - \\
Neva & 1 & 4 & - & - \\
Pençgâh & - & 2 & - & - \\
Rast & 2 & - & - & - \\
Sabâ & - & 2 & - & - \\
Segâh & - & 1 & - & 1 \\
Sünbüle & 1 & - & - & - \\
Uşşak & - & 1 & - & - \\
Toplam & 14 & 18 & - & - \\
\hline
\end{tabular}

Tablo 3’te görüldüğü üzere MSS'deki dini musiki eserleri 15 ayrı makamda kaleme alınmıştır. En çok sırasıyla Hüseyni, Neva, Muhayyer, Uşşak, Acem, Rast, Acem Aşiran, Eviç, Pençgah ve Saba makamları yer alırken Aşiran 
Buselik, Buselik, Irak, Segâh, Sünbüle makamlarında birer eserin varlığı dikkat çekicidir. İlahilerde nicel bağlamda Hüseyni makamı öne çıkarken tesbihlerde Acem ve Uşşak makamı kısmen öndedir. İlahilerde Hüseyni makamının peşinden Eviç, Muhayyer ve Rast makamları gelirken tesbihlerde bu sırayı Neva, Pençgah ve Saba makamı izlemektedir. Tevhid ve ayin-i şerif'te sadece birer örnek bulunduğundan Rast ve Muhayyer makamları öne çıkmaktadır.

Yine tablo 3'teki sıradan hareketle tesbihlerde görülen Acem makamı günümüzdeki Acem makamıyla büyük ölçüde benzerlik taşımakla birlikte bir eserin (MSS 171-2) bağlı olduğu makamın doğası gereği dügâh perdesinde karar vermek yerine Acem perdesinde kaldığ 1 tespit edilmiştir. Ancak eserin $A+B+C$ biçiminde kümelenen form yapısı incelendiğinde Ali Ufki her ne kadar bir dönüş işareti koymasa da eserin B bölümünde bitiş ihtiyacı hâsıl olduğundan Acem makamı içinde değerlendirmekte herhangi bir tereddüt yaşanmamıştır.

\section{Görsel 1}

Acem Tesbih, MSS 171-2
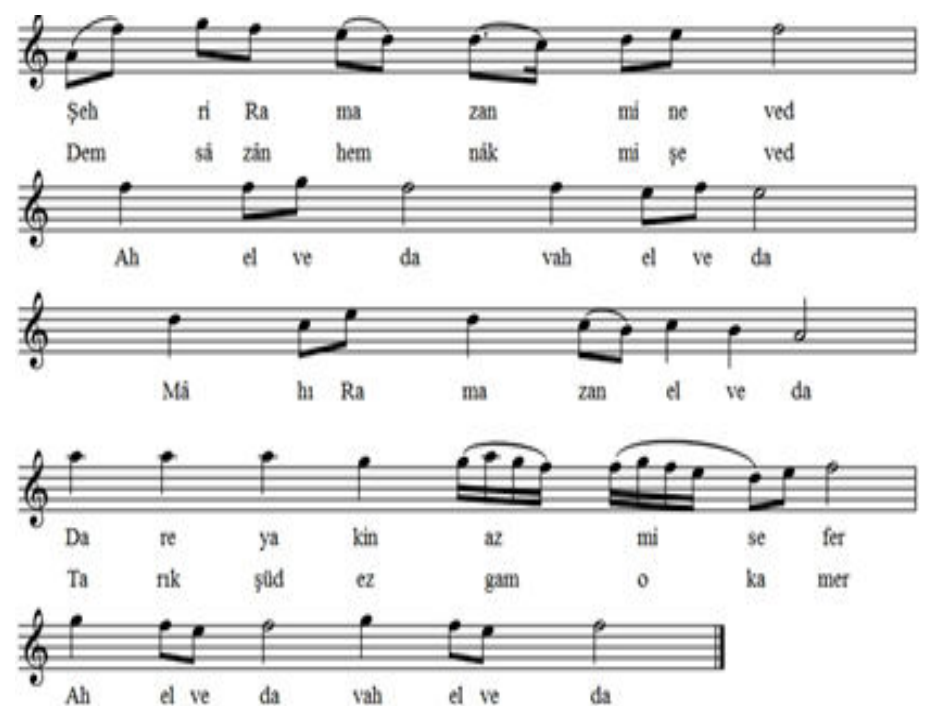

(Cevher, 2003, s. 575)

Hem ilahi hem de tesbih türlerinde birer örneği bulunan MSS'de Acemaşiran makamında ilahi türünde bulunan eser (MSS 300-2), günümüzdeki Acemaşiran makamıyla önemli ölçüde benzerlik taşmaktadır. Nitekim Ali Ufki bu eserin donanımında dizek üzerinde dördüncü çizgiye yerleştirdiği bemol işaretiyle dönemin Nihavend günümüzün ise Kürdi perdesini göstererek makamın özelliğini ortaya koymuştur. Ancak tesbih türü altında bulunan eserin (MSS 170-2) makam organizasyonu günümüzden ziyade döneminin özellikleriyle önemli ölçüde benzerlik taşımaktadır. 17'nci yüzyılın önde gelen makam teorisyenlerinden Kantemiroğlu (Tura, 2001, s. 105) Acemaşiran makamını Acem makamının bir terkibi olarak gördüğünü söyleyerek ince ve kalın perdelerde Acem makamı gibi hareket edip Acemaşiran perdesinde karar kılan bir makam olarak tanımlamakta ve yine başka bir yerde (Tura, 2001, s. 76) hem Dügâh hem de Acem perdesinde karar verebildiğini belirtmektedir. Söz konusu bu tesbihte Ali Ufki'nin eseri puandorglu bir Acemaşiran perdesi üzerinde bitirmesi eserin Acemaşiran özelliğini öne çıkarmaktadır. Zira Ali Ufki’nin kullandığı puandorg işareti günümüzdeki kullanışından farklı olarak eserin bitişini gösteren bir anlama tekabül etmektedir.

\section{Görsel 2}

Acem Aşiran İlahi, MSS 300-2

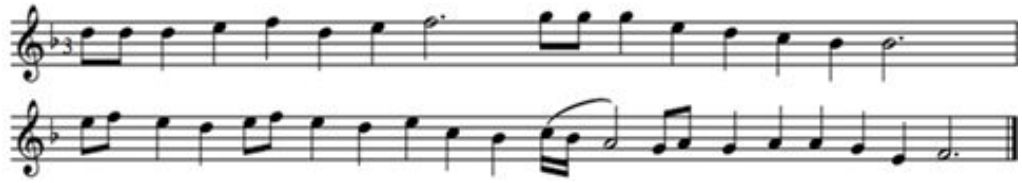

(Cevher, 2003, s. 892)

Her ne kadar fasıl başlığı altında Buselik Aşiran'a bağlı üç ilahi karşımıza çıksa da söz konusu bu makama büyük ölçüde uyan bir ilahi (MSS 302-2) bulunmaktadır. Makam organizasyonu olarak bu eser her ne kadar Dügâh perdesinde karar verse de dönemin kaynaklarından Kantemiroğlu'nun (Tura, 2001, s. 105) verdiği bilgilerden hareketle Aşiran Buselik makamının gerek kalın gerekse ince sesli perdelerde Buselik makamı gibi hareket edip Aşiran perdesinde karar kıldığını biliyoruz. Ancak bu fasıldaki ilahinin Buselik makamından çok Buselik Aşiran 
yahut Aşiran Buselik olarak tanımlanmasındaki yegâne mantık bizzat Muhayyer perdesinin çekim merkezi üzerinden başlamasıdır. Nitekim Kantemiroğlu (Tura, 2001, s. 81-82) Buselik makamına özel olarak yaptığ1 tanımda makamın Dügâh perdesinde başlamak suretiyle kendi perdesi üzerinden Çargâh perdesine çıkıp Hüseyni makamında olduğu gibi tiz perdelere dek hareket edebildiğinden söz etmektedir. Dönemin bu önemli kaynağındaki her iki tanım karşılaştırıldığında söz konusu ilahiyi Buselik Aşiran olarak tanımlamak yanlış olmayacaktır.

\section{Görsel 3}

Buselik Aşiran İlahi, MSS 302-2

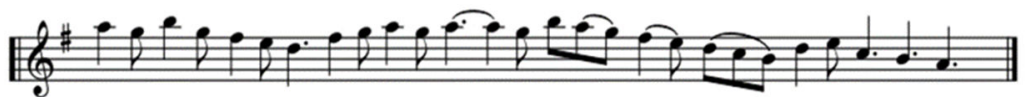

(Cevher, 2003, s. 896)

Tablo 3'te görülen Buselik makamındaki tek örnek Neva faslı içinde yer alan bir tesbih eserde (MSS 121-3) mevcuttur. Söz konusu eserin Neva faslı içinde yer alması şaşırtıcı değildir; zira Safiyyüddin'den başlamak üzere Meragî, Şirvânî, Lâdikli ve Hacı Büke gibi tarihi kaynaklarda Neva makamı Buselik dizisi içinde tarif edilmiştir (Levendoğlu, 2002, s. 136). Dönemin kaynaklarından Kantemiroğlu (Tura, 2001)'nun yaptığı Neva tarifi ise günümüzdekine benzer niteliktedir.

\section{Görsel 4}

Buselik Tesbih, MSS 121-3
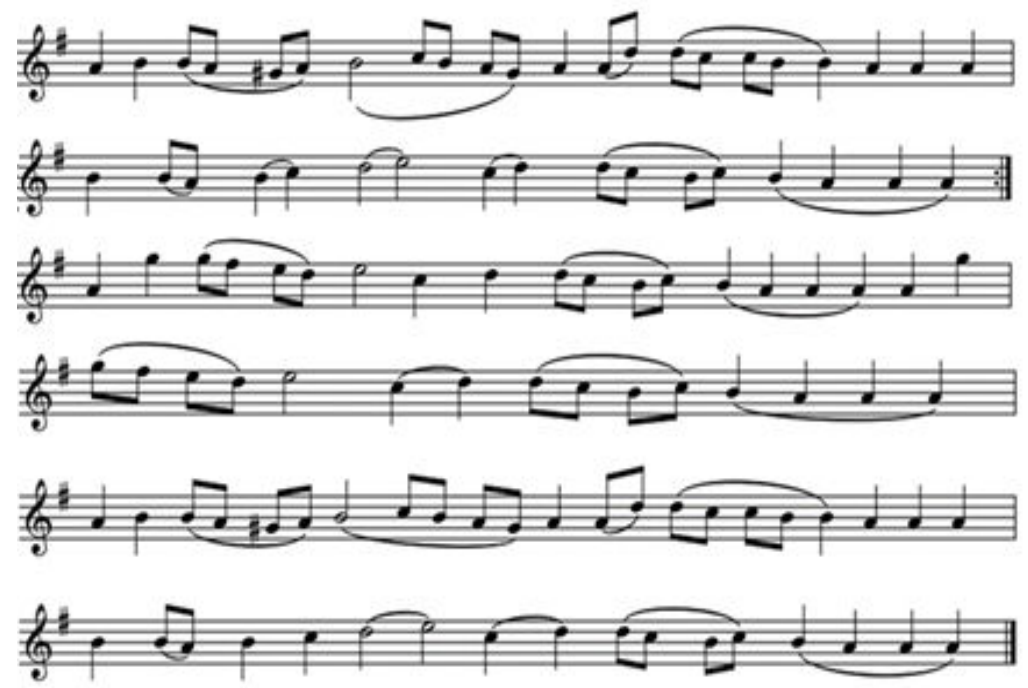

(Cevher, 2003, s. 445)

MSS'de dini musiki türleri içerisindeki Eviç makamı sadece iki ilahide (MSS 247-2, 248-1) karşımıza çıkmaktadır ve her ikisi de döneminin Eviç makamı özelliklerini büyük ölçüde karşılamaktadır. Dini eserler arasında nicel olarak sayı üstünlüğüne sahip olan Hüseyni makamı ise dört ilahi ( MSS 54-2, 81-2, 311-1, 315-3) ve bir tesbih (MSS 315-2) üzerinden varlık kazanmaktadır. İlahi türündeki eserlerde ezgi organizasyonu gerek dönemindeki gerekse günümüzdeki Hüseyni makamıyla birebir eşleşirken tesbih türündeki makam organizasyonu Neva ile Hüseyni arasında giden bir seyir özelliği taşımasına ve hatta Cevher (2003)'de Neva olarak işaretlenmesine rağmen bu çalışmada Hüseyni içinde ele alınmıştır.

\section{Görsel 5}

Eviç İlahi, MSS 248-1

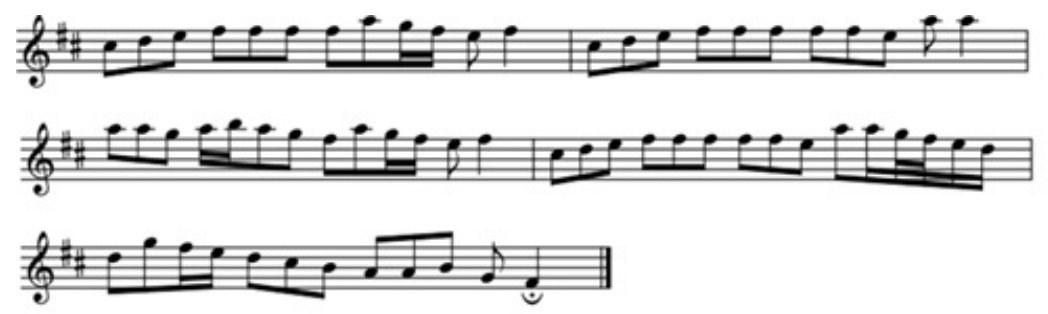

(Cevher, 2003, s. 771) 
Tablo 3'te yer alan Irak makamı yalnızca bir tesbih (MSS 253) ile temsil edilmektedir. Eviç faslında yer alan bu eser Dügâh perdesi çevresinde seyre başlamak suretiyle yarattığı Uşşak etkiyle Eviç, Hüseyni, Neva ve Dügâh perdeleri üzerinden Irak perdesinde karar vermektedir. Nitekim bu yapı gerek döneminin gerekse günümüzün Irak makamı ile büyük ölçüde benzerlik göstermektedir.

\section{Görsel 6}

Irak Tesbih, MSS 253

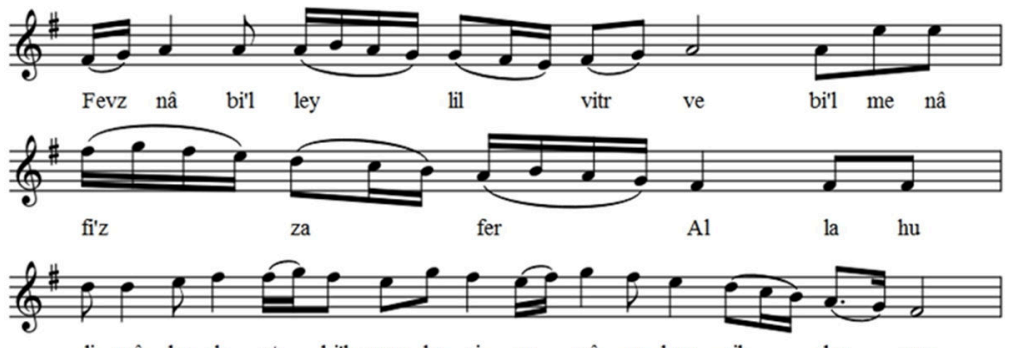

li mâ be de et bi'l maz ha ri en vâ ru hay ril be şer
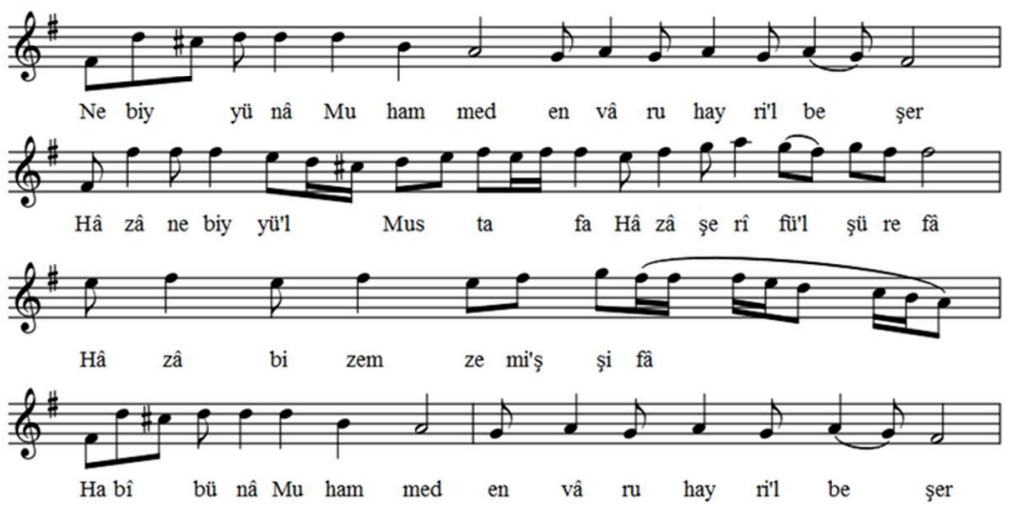

(Cevher, 2003, s. 788)

MSS'deki dini nitelikli eserlerde öne çıkan diğer bir makam Muhayyer'dir. Tablo 3'te görüldüğü üzere bu makamda iki ilahi (MSS 85-2, 300-1), bir tesbih (MSS 317-1) ve bir ayin-i şerif (MSS 84-2) bulunmaktadır. Muhayyer faslında yer alan ilk ilahi (MSS 85-2) Muhayyer perdesi üzerinde seyre başlamak ve Tiz Çargâh perdesini duyurmak sureti ile Muhayyer perdesinde karar vermektedir. Ancak kuvvetle muhtemel bu eserin tiz durak perdesinde değil de form olarak B cümlesine denk gelen müzikal örgüde karar verdiği ön görülmektedir. Başta dönemin önemli kaynaklarından Kantemiroğlu Edvarı (Tura, 2001) olmak üzere dönem öncesindeki Bedri Dilşâd, Hızır bin Abdullah, Yusuf bin Nizameddin Kırşehrî, Seydi ve Kadızade Tirevi'de Muhayyer makamı mutlak suretle Dügâh perdesinde karar kılmaktadır (Levendoğlu, 2002, s. 131). Ayrıca Kantemiroğlu (Tura, 2001, s. 69-70) bu makamla ilgili yaptığı tarifte ezgisel seyrin Hüseyni perdesinde başladığını, tiz perdelerde gezindikten sonra yine Hüseyni perdesini duyurmak suretiyle Çargâh üzerinden Saba perdesini işleyerek Dügâh perdesinde karar kıldığını belirtmektedir. Seyir bakımından söz konusu bu ilahinin Saba çeşnisi kuralları haricinde Hüseyni perdesi üzerinden seyir hareketi göstermesi nedeniyle dönemin kaynaklarıyla benzerlik gösterdiği söylenebilir.

\section{Görsel 7}

Muhayyer Ilahi, MSS 85-2

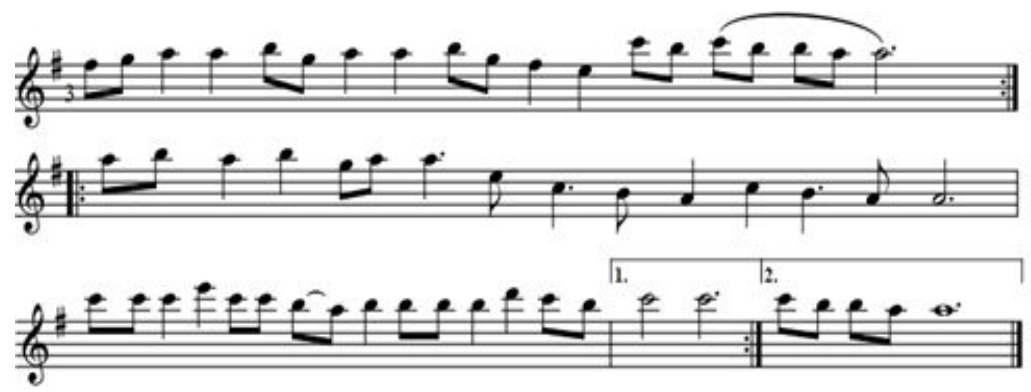

(Cevher, 2003, s. 343)

Aşiran Buselik faslında yer alan ikinci ilahi (MSS 300-1) ise bu makam yapısından çok kısmen Muhayyer makamının özellikleriyle uyuştuğu tespit edilmiştir. Her ne kadar Aşiran Buselik ya da günümüzdeki ismi ile 
Buselik Aşiran makamı Hüseyni Aşiran perdesinde karar kılsa da söz konusu ilahinin Dügâh perdesinde tam karar vermesi ve Ali Ufki'nin notaya aldığ 1 diğer Aşiran Buselik eserlerden durak bağlamında farklılık içermesi nedeniyle eserin karakteristik olarak daha çok Muhayyer makamı etkisinde olduğunu söylemek mümkündür. Tesbih türü içinde Muhayyer makamının tek örneği ise Hisar faslında yer almakla birlikte gerek döneminin gerekse günümüzün Muhayyer makamı özelliklerini taşıdığı söylenebilir. MSS'de tek örneği bulunan Ayin-i Şerif (MSS 84-2) de Muhayyer faslı içerisinde yer almaktadır. Genel karakteri itibarı ile her ne kadar ağırlıklı olarak tiz seslerde seyir özelliği göstermese de gerek bağlı olduğu fasıl gerekse ilgili makamın MSS içindeki diğer örnekleri göz önüne alınarak Muhayyer makamının özelliklerine sahip olduğu söylenebilir.

Tablo 3'te yer alan Neva makamı bir ilahi ve dört tesbih üzerinden varlık kazanmaktadır. Hisar faslında yer alan bir ilahi (MSS 317-3) ile üç tesbih (MSS 315-1, 316-1, 316-2) hem dönemin hem de günümüzün makam tariflerine uygun olarak öne çıkarken Neva faslı içinde yer alan diğer tesbih (MSS 123-3) karar dışı bir perdede bitiş özelliği gösterse de tipik bir Neva makamı özelliğine sahip olduğu söylenebilir. Nitekim Nâyî Osman Dede, Tanburi Küçük Artin, Marmarinos ve Seyyid Mehmet Emin tarafından verilen tariflerde Neva makamının karar sesi Neva perdesi olarak gösterilmiştir (Levendoğlu, 2002, s. 141). Kantemiroğlu (Tura, 2001, s. 61) da yaptığ Neva açıklamasında makamın karar seslerinden birinin Neva perdesi olduğunu belirtmektedir. Keza bu eserin ezgi organizasyonu makamın doğası gereği Neva perdesi çevresinde seyre başlayıp devamında Dügâh, Segâh, Çargâh, Rast ve Hüseyni perdelerini duyurmak sureti ile Neva perdesinde yarım karar vermektedir. İkinci satırda Gerdaniye ve Eviç perdelerini göstererek Gerdaniye ve Segâh arasındaki sıra sesleri duyurmak sureti ile benzer bir şekilde bir önceki cümlenin ardıl motifini tekrar ederek bu kez Hüseyni perdesinde asma karar gösterir. Ancak eserin yeniden başa dönerek ilk bölümle sonlanması kuvvetle muhtemeldir. Bu nedenle ezgisel yapının kararını Neva perdesi olarak işaretlemek yanlış olmayacaktır.

\section{Görsel 8}

Neva Tesbih, MSS 315-1

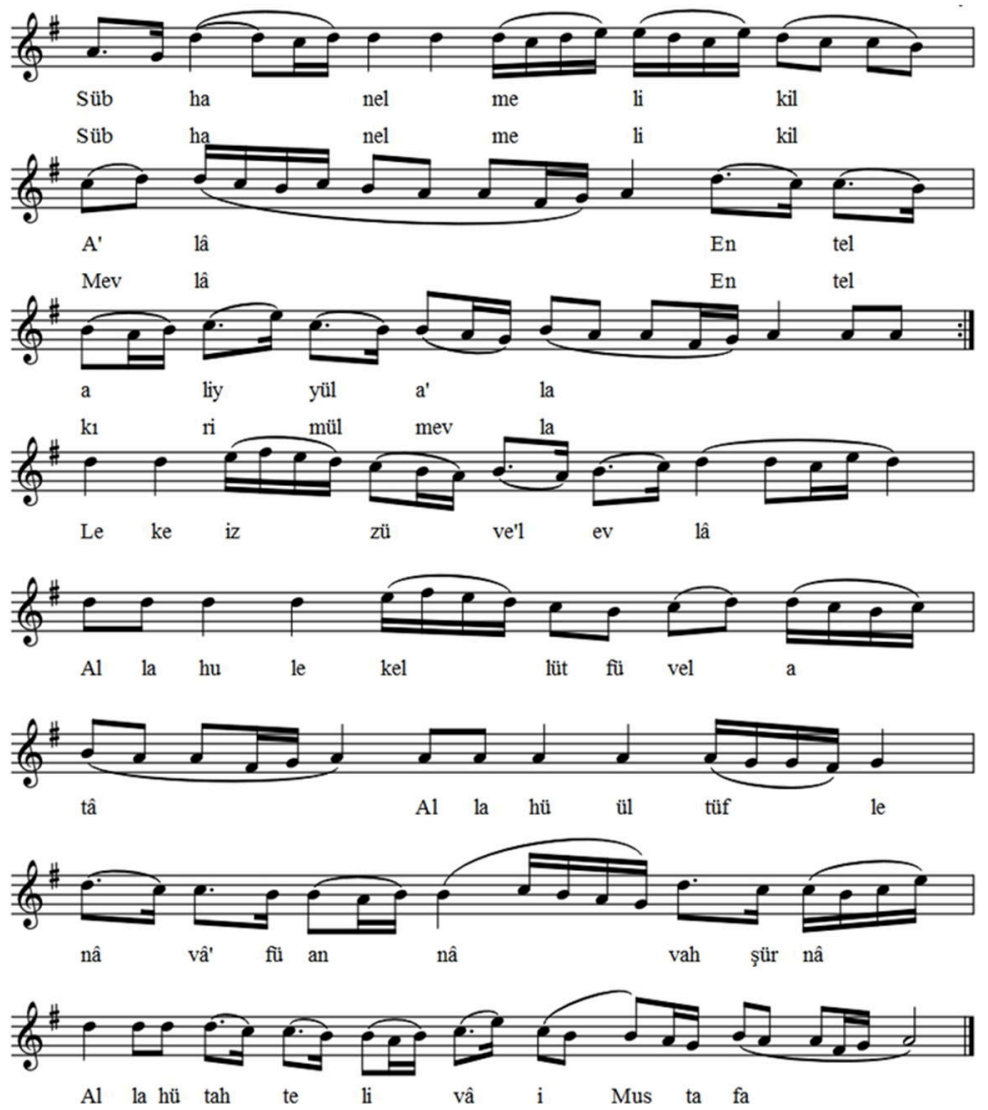

(Cevher, 2003, s. 915)

Tablo 3'te görüldüğü gibi MSS'deki dini eserlerin ikisi Pençgâh makamındadır. Her iki eser de Rast faslında yer almaktadır ve Ali Ufki bu eserleri Rast-1 Pençgâh olarak tanımlamıştır. Nitekim dönemin kaynaklarından Kantemiroğlu (Tura, 2001, s. 49) da Pençgâh makamını Rast makamına uyan, ona tabi olan bir terkip olarak tanımlamaktadır. Buna göre ilk tesbih (MSS 233-1) makamın doğası gereği Rast perdesi ekseninde seyre başlayıp güçlü ses olan Neva perdesini duyurmak sureti ile Rast perdesinde tam karar vermektedir. Akabindeki ikinci satırda ezginin seyri Gerdaniye perdesi çevresine kayarken Eviç ve Hüseyni seslerini duyurmak kaydı ile Neva 
perdesinde Rastlı bir asma kalış sergilenmektedir. Ardında yer alan seyir ise eserin Pençgâh yapısını gösterir niteliktedir. Neva etkili motif Hicaz/Uzzal perdesiyle Rast perdesinde Pençgâhlı bir kalış gösterirken Neva ve Hüseyni perdesi üzerinden Rast perdesinde Rastlı bir tam kalış sergilemektedir. Diğer tesbihte (MSS 235) ise notanın hiçbir yerinde Pençgâh karakterine ait Uzzal/Hicaz perdesi yazılmamıştır. Oysa ki diğer eserde bu perde tanımlıdır. Ancak yine de söz konusu eserin Neva çevresinde seyre başlayıp inici-çıkıcı bir seyir özelliği arz etmesinden dolayı Pençgâh olarak değerlendirilebilmekle birlikte Çargâh ve Uzzal/Hicaz perdelerinin hangi durumda dönüşümlü kullanıldığı sorusu ne yazık ki cevapsız kalacaktır.

Görsel 9

Pençgah Tesbih, MSS 233-1

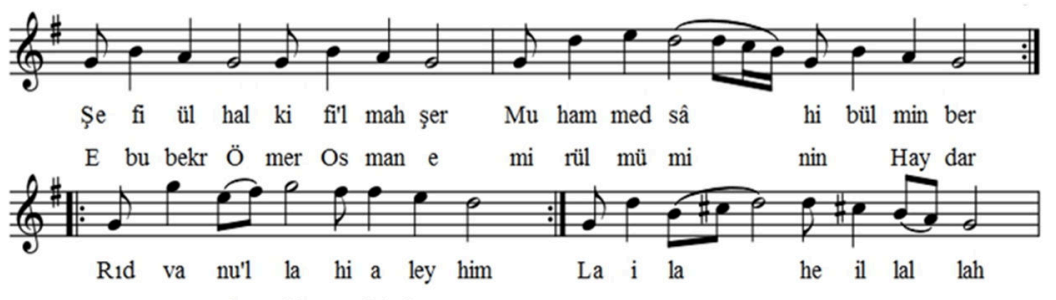

Hü ve's sâ ki a lel kev ser

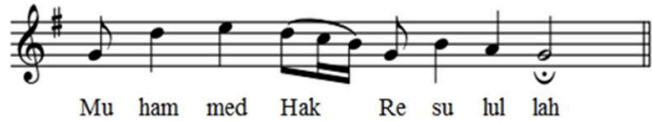

(Cevher, 2003, s. 734)

Tablo 3'te yer alan Rast makamında iki ilahi (MSS 231-2, 233-2) ve bir tevhid (MSS 216) bulunmaktadır. Her üç eser de bağlı bulunduğu fasıl ile uyum göstererek gerek dönemindeki gerekse günümüzdeki Rast makamını temsil etmektedir. Yine aynı tabloda yer alan Saba tanımlı iki tesbih (MSS 186-1, 186-2) ise her ne kadar saba perdesi belirtilmese de Ali Ufki'nin başlıkta ve tasnif ettiği fasılda belirttiği gibi Saba makamı içinde değerlendirilebilir. Nitekim dönemin kaynaklarından Kantemiroğlu (Tura, 2001, s. 72) Çargâh ile Neva arasındaki yarım perdenin makama ismini veren perde olduğunu vurgularken burada da bağlı olduğu makamın doğasına uygun bir seyir yapısının öne çıtı̆̆ını söylemek mümkündür.

\section{Görsel 10}

Rast Ilahi, MSS 233-2
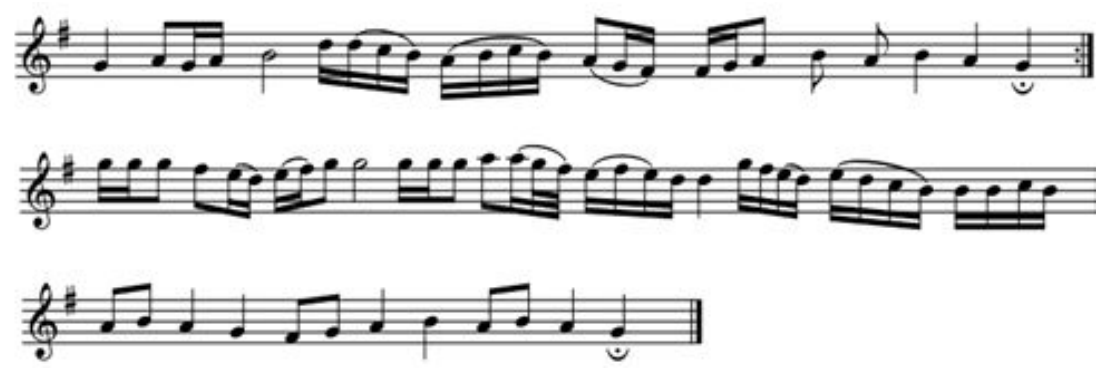

(Cevher, 2003, s. 735)

Tablo 3'te yer alan bir Segâh makamı kısmen tartışmalıdır. Zira Ali Ufki bu tesbihi (MSS 123-2) MSS'de Neva faslı içinde göstermiş, Cevher (2003) ise, yine söz konusu bu eseri neva makamı olarak işaretlemiştir (s. 946). Yapılan analiz sonucunda eserin karar yapısı haricinde Neva makamının doğal seyir özelliklerini gösterdiği ancak form bağlamında her iki bölüm içinde de yarım ve tam kararlarını Segâh perdesi üzerinde konumladığı tespit edilmiştir. Tesbih bağlı olduğu fasıl gereği Neva perdesi ekseninde seyre başlayıp Dügâh, Rast, Segâh, Çargâh ve Neva perdelerini duyurmak sureti ile Segâh perdesinde kalış gösterirken akabinde Eviç ve Gerdaniye perdeleri üzerinden Hüseyni ve Neva perdelerini duyurmak sureti ile Segâh perdesinde bitiş göstermektedir. Tüm bu verilerden ve Kantemiroğlu Edvarı'nda tanımlanan Segâh tanımından (Tura, 2001, s. 58) hareketle bu eseri Segâh makamı olarak işaretlemek yanlış olmayacaktır.

MSS'de yer alan ender Sünbüle makamlarından biri de bir ilahi (MSS 313-1) üzerinde varlık bulmaktadır. Söz konusu eser her ne kadar Hisar faslında yer alsa da Ali Ufki eserin Sünbüle makamında olduğunu belirtmiştir. Nitekim eserde, makamının doğası gereği Saba perdesine ilişkin bir bilgi verilmezken seyir karakteri olarak Muhayyer perdesi ekseninde seyre başlaması Ali Ufki’nin belirttiği makama uygunluk göstermesi bakımından önemlidir. Nitekim Kantemiroğlu (Tura, 2001, s. 84) bu makamı perde sahibi bir makam olarak tanımlayıp Sünbüle perdesini Muhayyer ile Tiz Segâh arasındaki bir yarım perde olarak tanımlamaktadır. Yine Kantemiroğlu, 
Sünbüle makamını tanımlarken Muhayyer perdesinde başladığını, Tiz Hüseyni perdesine dek çıktığını, Tiz Segâh veya kendi perdesi üzerinden Gerdaniye, Acem, Hüseyni perdelerine düşerek Saba makamı akışıyla son bulduğunu belirtmektedir. MSS'deki bu eserin de kısmen bu tarifle uyuştuğu söylenebilir.

\section{Görsel 11}

Sünbüle Illahi, MSS 313-1

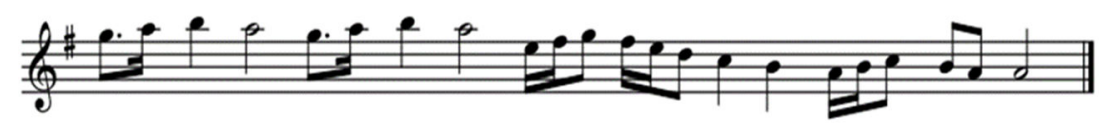

(Cevher, 2003, s. 912)

Tablo 3 'teki son makam olan Uşşak makamında yalnızca bir tesbih (MSS 317-2) bulunmaktadır. Nitekim bu eser hem MSS'deki diğer Uşşak eserlerle hem de günümüzün Uşşak yapısıyla benzerlik göstermektedir.

Görsel 12

Uşşak Tesbih, MSS 317-2

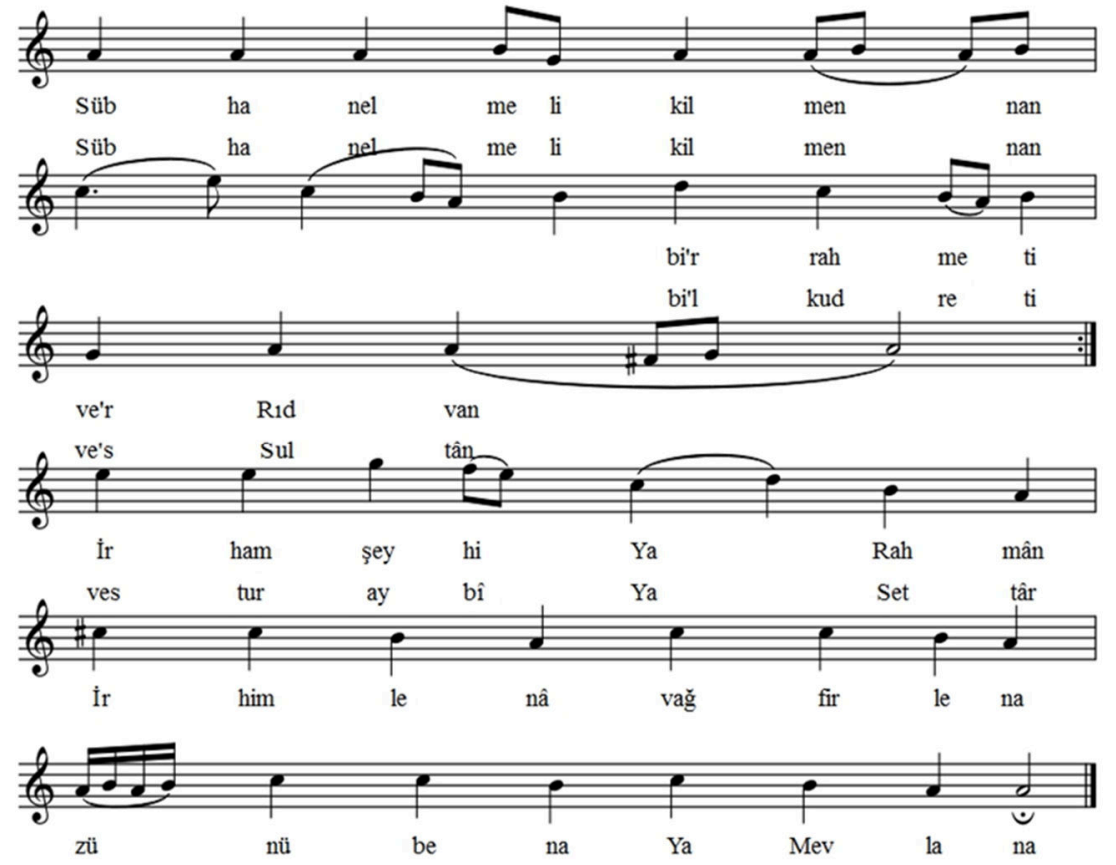

(Cevher, 2003, s. 922)

Tablo 4

MSS'deki Dini Eserlerin Usul Bakımından Dă̆ılımı

\begin{tabular}{lcccc}
\hline Usul & İlahi & Tesbih & Tevhid & Ayin-i Şerif \\
\hline Düyek & 3 & 6 & - & - \\
Evfer & - & 2 & - & - \\
Evsat & 1 & - & - & - \\
Semai & 4 & 1 & 1 & - \\
Sofyan & 4 & 4 & - & 1 \\
Belirlenemeyen & 2 & 5 & 1 & 1 \\
Toplam & 14 & 18 & - & 1 \\
\hline
\end{tabular}

Tablo 4'te görüldüğü üzere MSS'deki dini nitelikli eserler Düyek, Evfer, Evsat, Semai ve Sofyan olmak üzere beş farklı usul içinde yer almaktadır. Tablodaki sekiz eserin usul organizasyonu ise belirlenememiştir. Söz konusu belirsizlik durumu hem ölçüsü belli olup gelenekle ilişkili olarak belirli bir usul kalıbına tekabül etmeyen hem de ölçü bazında orantısız olarak gelişen bir ritmik yapıyı kapsamaktadır. Buna göre MSS'deki dini eserler içinde Düyek usulü nicel olarak öne çıkarken bu usulü Sofyan ve Semai takip etmektedir. Evfer ve Evsat usullerinin ise genel dağılım içinde azınlık kaldığını belirli bir usul dairesinde belirlenemeyen eserlerin de azımsanmayacak oranda olduğunu belirtmek gerekir.

Tablo 4'te görüldüğü gibi üç ilahi ve altı tesbih Düyek usulündedir. Cevher (2003)'in de vurguladığı gibi burada Düyek olarak tanımlanan usullerin günümüzdeki haliyle büyük ölçüde ilgisi yoktur ancak $(2+2+2+2)^{\prime} l i k$ bir düzüm içinde gelişmektedir (s. 41). Uludemir (1985) ise, MSS'deki Düyek yapıyı dört vuruşa tekabül eden 2/4'lük 
bir ölçü içinde tanımlamaktadır (s. 16). Dönemin kaynaklarından Kantemiroğlu bu usulü düm (1) tek (2) tek (1) düm (2) tek (2) biçiminde tarif ederken (Tura, 2001, s. 166), Ali Ufki, [Turc 292]'de Düyek usulünü büyük ölçüde günümüzdeki yapısına benzer bir biçimde tanımlama yoluna gitmiştir. Buna göre bir ilahide (MSS 247-2) dizek başında Düyek usulünü gösteren bir işaret yer alırken diğer iki ilahi (MSS 313-1, 315-3) yukarıda tarif edilen usul yapısı içinde varlık göstermektedir. Tesbih eserlerde (MSS 170-2, 171-2, 235, 315-1, 315-2, 316-1) ise yer yer zaman deformasyonlarına rağmen Düyek usulünü işaret eden usul göstergeleriyle birlikte dönemin kaynaklarında belirtilen Düyek tarifleriyle büyük ölçüde örtüşmektedir.

Tablo 4'te yer alan Evfer usulünü yalnızca iki tesbih üzerinde tespit etmekteyiz. Ancak buradaki her iki eserin usul yapısı birbirinden farklılık arz etmektedir. İlk tesbih (MSS 186-1) MSS'deki diğer Evfer usulündeki eserlerin aksine $(4+5+4+5)$ kesitli bir ritmik yapıya sahiptir ve porte başında 18 rakamını belirten bir usul işareti mevcuttur. Nitekim Cevher (2003)'in de vurguladığ 1 gibi MSS'de Evfer olarak belirtilen eserlerde günümüzdeki kullanımından farklı olarak $(3+2+2+2)$ düzüm yapısı öne çıkmaktadır (s. 41). Ancak dönemin kaynaklarına bakıldığında Kantemiroğlu Evfer'i düm (2) te-ke (1) te-ke (1) düm (2) tek (3) biçiminde tanımlarken (Tura, 2001, s. 166), Ali Ufki'nin Turc 292 yazmasında biri 3/2'lik diğeri ise 6/2'lik olmak üzere iki tip Evfer tarifi yapması dikkat çekicidir. Yine de her iki teorik çerçeve Evfer usulünü düzüm olarak ayrıştırsa da üçün katları üzerinden açıklamaktadır. Bu usuldeki diğer tesbih (MSS 233-1) ise, Cevher (2003)'in belirtmiş olduğu Evfer tanımına birebir uymaktadır (s. 41). Ancak bu eserin dizek başında bağlı olduğu usul yerine Düyek usulü göstergesi kullanılmıştır.

Tablo 4'te yer alan tek Evsat usulü bir ilahide (MSS 231-2) yer almaktadır. MSS'de bu usule dair herhangi bir emare yoktur. Ancak eserin içinde bulunduğu $(5+4+4)$ yapısı dönemin kaynaklarından Kantemiroğlu'nun Evsat için yaptığı $26(5+4+4+5+4+4)$ zamanlı tarifle uyuştuğundan (Tura, 2001, s. 164) ilahiyi söz konusu usul dairesi içinde ele alabiliriz.

Tablo 4'te görülen Semai usulü dört ilahi (MSS 85-2, 248-1, 300-2, 302-2) bir tesbih (MSS 186-2) ve bir tevhid (MSS 216) üzerinde temsil edilmektedir. MSS'de bu usulle kaleme alınan notaların başında büyük ölçüde 3 rakamını işaret eden göstergeler mevcuttur. $\mathrm{Bu}$ bağlamda günümüzdeki Semai yapıyla birebir uyuştuğu söylenebilir. Ancak Cevher (2003) MSS'deki Semai yapısının bağlı olduğu akış gereği günümüzdeki Yürük Semai ile benzerlik taşıdığını belirtmektedir (s. 42). Dönemin kaynaklarına bakıldığında Kantemiroğlu'nun bu usulü; düm (1) tek (1) tek (1) düm (1) tek (2) biçiminde (Tura, 2001, s. 167), Ali Ufki’nin ise Turc [292]'de aynı tanımı bir rakamına karşılık gelen zamana dörtlük nota, ikiye karşılık gelen zamana ise ikilik nota değeri vermek suretiyle kayda aldığı görülmektedir. Yeniden tabloya dönecek olursak iki eser (MSS 186-2, 302-2) haricinde Semai usulünü gösteren işaretler yer alırken bir ilahinin başında Devr-i Revan usulü yazısı yer almasına karşın hem portedeki üç rakamını gösteren işaret hem de usul işleyişi bakımından yukarıdaki tariflerle örtüşen bir zaman yapısına sahip olduğu tespit edilmiştir.

Tablo 4'te görüldüğü gibi Düyek usulünden sonra MSS'deki en fazla dini musiki repertuvarı dört ilahi ( MSS 542, 81-2, 233-2, 317-3) ve yine dört tesbih ( MSS 121-3, 171-2, 316-2, 317-1) ile Sofyan usulünde yazılmıştır. Uludemir (1985) MSS'de Ali Ufki'nin “Sofyane” olarak belirtiği usulün 2/4'lük (2+2), 4/4'lük (2+2+2+2), 8/8'lik $(3+2+3)$ kestiler içinde gelişme gösterdiğini belirtmiştir (s. 15-17). Yine Ali Ufki, Turc [292]'de bu usulü günümüzdeki kullanımına benzer bir biçimde tarif ederken Kantemiroğlu düm (2) te-ke (2) biçiminde tarif etmektedir (Tura, 2001, s. 167). Tüm bu bilgilerden hareketle MSS'deki Sofyan usullü ilahi ve tesbihlerin yer yer görülen ritmik deformasyonlara rağmen hem günümüzün hem de dönemin kaynaklarıyla uyumlu bir nitelik arz ettiği söylenebilir. Burada vurgulanması gereken bir diğer husus ise Ali Ufki’nin Sofyan usulündeki bir ilahi (MSS 233-2) ve tesbihte (MSS 317-1) MSS'de Düyek usulüne karşılık gelen işaretleri kullanmış olmasıdır.

Tablo 4'te belirtilen usulü belirlenemeyen eserler de nicel olarak dikkat çekicidir. Buna göre iki ilahi (MSS 3111, 300-1) beş tesbih (MSS 123-2, 123-3, 171-3, 253, 317-2) ve bir ayin-i şerif (MSS 84-2) MSS'de zaman organizasyonu bakımından belirli bir usul formunda karşılığ bulunmayan repertuvar bileşenleridir. Elbette ki bu belirsizlikte iki tip yapı karşımıza çıkmaktadır. İlk yapı, zaman organizasyonu bakımından tanımlanabilir bir ölçüye uymayan; ikinci yapı ise tanımlanabilir bir ölçü içinde yer alıp belirli bir usul kalıbına tekabül etmeyen eserleri içermektedir. Bu başlık altında vurgulanması gereken husus Ali Ufki'nin her iki tipteki bazı eserlerin başına usulü belirten işaretleri yazmış olmasıdır. Örneğin bir tesbihte (MSS 123-2) Düyek usulünü karşılayan gösterge yer almasına karşın zaman organizasyonunun 10 zamanlı ve $(3+3+2+2)$ düzümlü bir yapı içinde olduğu tespit edilmektedir. Keza bir diğer tesbihte (MSS 171-3) 10 rakamını belirten bir işaret yer alsa da ritmik deformasyonlara rağmen eserin $(4+4+4+6)$ usul kesiti içinde yer aldığı görülmektedir. Buna karşın yine bir tesbihte (MSS 123-3) Nim Sakil usulüne karşılık gelen 12 rakamı porte başında yer alsa da zaman organizasyonun belirli bir metrik yapıya tekabül etmediği görülmektedir. Aynı şekilde ayin-i şerif (MSS 84-2) eserde Düyek usulünü gösteren işaret mevcut olmasına karşın belirli bir usul ve ölçüyü temsil etmediği tespit edilmiştir. 
Tablo 5

MSS'deki Dini Eserlerin Form Yapısı Bakımından Dağılımı

\begin{tabular}{lcccc}
\hline Form & İlahi & Tesbih & Tevhid & Ayin-i Şerif \\
\hline Bir Bölümlü & 4 & - & - & - \\
İki Bölümlü & 8 & 5 & - & 1 \\
Üç Bölümlü & 2 & 8 & - & - \\
Dört Bölümlü & - & 2 & - & - \\
Beş Bölümlü & - & 1 & - & - \\
Altı Bölümlü & - & 2 & 1 & 1 \\
Toplam & 14 & 18 & 1 & \\
\hline
\end{tabular}

Tablo 5’te görüldüğü üzere MSS'deki dini eserlerin form yapıları altı farklı biçimde varlık göstermektedir. Burada nicel bakımından öne çıkan ilahi ve tesbihler arasında bir karşılaştırma yapıldığında ilahilerin dar kurulumlu müzik cümleleri ve motiflerle birlikte az bölümlü ve daha küçük anlatımlı müziksel ifadelerden oluştuğu; tesbihlerin ise tüm bunların aksine geniş kurulumlu müzik cümleleri ve motiflerle birlikte çok bölümlü ve uzun anlatımlı ifadelerden oluştuğu görülmektedir. Ancak bu yapıların bazılarında motif ve cümle bağlamında tutarlı bir form yapısı bulunmamaktadır. Tevhid ve ayin-i şerif çatısındaki eserlerde ise iki bölümlü bir form yapısı öne çıkmakla birlikte bu yapının kısa anlatımlı bir ses organizasyonu içermesi dikkat çekicidir.

Yeniden Tablo 5'e dönecek olursak ilahi çatısı altında yer alan eserlerin en fazla iki bölümlü olduğu görülmektedir. İki bölümlü tüm ilahiler $(\mathrm{A}+\mathrm{B})$ formundadır. Bu sıralamayı bir bölümlü ve üç bölümlü ilahiler izlemektedir. Üç bölümlü ilahi (MSS 315-1) $(\mathrm{A}+\mathrm{B}+\mathrm{C})$ biçiminde üç farklı cümlenin birleşiminden oluşmaktadır. Tesbih çatısındaki eserlerin ise en fazla üç bölümlü olduğu, bu sırayı iki, dört, altı ve beş bölümlü yapıların izlediği görülmektedir. İki bölümlü tesbihler (MSS 123-2, 123-3, 186-2, 233-1, 316-2) (A+B) biçiminde gelişirken üç bölümlü tesbihlerin iki tipte; $(\mathrm{A}+\mathrm{B}+\mathrm{A})$ (MSS 121-3, 186-1, 235) ve (A+B+C) (MSS 171-1, 171-2, 171-3, 315-2, 317-1) şeklinde oluştuğu görülmektedir. Yine iki tipte dört bölümlü tesbih bulunmaktadır. Bunlar $(\mathrm{A}+\mathrm{B}+\mathrm{C}+\mathrm{D})$ (MSS 316-1) biçiminde dört farklı bölümden oluşan bir örnek ile ana yapıda iki farklı ses organizasyonundan oluşup eser içinde varyantlarını teşkil eden $\left(\mathrm{A}+\mathrm{B}+\mathrm{A}^{1}+\mathrm{B}^{1}\right)$ (MSS 315-1) biçimli bir tesbih örneğidir. Beş ve altı bölümlü tesbihler ise tek tipte karşımıza çıkmaktadır. Beş bölümlü örnek $(A+B+C+D+C)(M S S ~ 253)$ biçiminde öne çıkarken, altı bölümlü yapı $(\mathrm{A}+\mathrm{B}+\mathrm{C}+\mathrm{B}+\mathrm{D}+\mathrm{B})(\mathrm{MSS}$ 170-2, 317-2) biçiminden oluşmaktadır.

Tablo 6

MSS'deki Dini Eserlerin Güfte Yapısı

\begin{tabular}{lcccc}
\hline Güfte Yapısı & Ilahi & Tesbih & Tevhid & Ayin-i Şerif \\
\hline Aruz & 6 & 15 & - & 1 \\
Hece & 6 & - & - & - \\
Belirsiz & - & 3 & - & - \\
\hline Nazım Şekli & & & - & - \\
\hline Gazel & 3 & 2 & - & - \\
Koşma & 3 & 2 & - & - \\
Mesnevi & 1 & - & - & - \\
Muhammes & 1 & 4 & - & - \\
Murabba & - & - & 1 \\
Semai & 3 & 10 & - \\
Belirsiz & 1 & & \\
\hline
\end{tabular}

Tablo 6'da görüldüğü üzere MSS'deki dini nitelikli eserler aruz ve hece ölçüleriyle yazılmış olup gazel, koşma, mesnevi, muhammes, murabba ve semai gibi nazım şekillerinden oluşmaktadır. Bunun yanında yapı ve şekil bakımından tanımlanamayan eserler de mevcuttur. Tür bazında değerlendirildiğinde ilahilerin yarısı hece diğer yarısı ise aruzlu yapıdadır. Heceli ilahiler nazım şekline bağlı olarak 8'li ve 11'li ölçülerde dengeli bir dağılım göstermektedir. Aynı zamanda bu durum koşma ve semai yapılarını ortaya koymaktadır. Aruzlu ilahilerde ise remel, recez ve hecez bahirleri öne çıkarken gazel, mesnevi, muhammes ve murabba gibi şekil yapıları bulunmaktadır. Tesbih eserlerde ise tabloda görüldüğü gibi tamamen aruz hâkimiyeti söz konusudur. Yalnızca üç eser güfte yapısı bakımından tanımlanır değildir. Ancak nazım şekli belirsizliği oldukça fazladır. Tesbihlerin remel, hecez, münserih, recez gibi çeşitli bahirlerde yazıldığı görülmektedir. Ayrıca gazel, mesnevi ve murabba şekil yapıları bulunmaktadır. Her iki tür haricinde kalan MSS'deki tevhid örneği yalnızca "Lâ İlâhe İllallah" lafzından oluştuğu için değerlendirme dışı bırakılırken ayin-i şerif' in bahri münserih'li ve gazel yapılı bir aruz örneği olduğu tespit edilmiştir. Söz konusu bu verilere ek olarak güftelerinin önemli bir bölümünün anonim olduğunu söylemek mümkündür. Sahibi belli güftelerin ise başta Ali Ufki olmak üzere Hatip Zâkiri Hasan Efendi, Eşrefoğlu Rumi, Ahmed Eflâki, Abdülehad Nuri, I. Ahmed, III. Murad ve Aziz Mahmud Hüdâi’ye ait oldukları tespit edilmiştir. 


\section{Sonuç}

Bu çalışmada MSS'de yer alan dini musiki eserleri başta makam ve usul organizasyonu ile form ve güfte yapısı olmak üzere anahtar, usul ve arıza işaretleri bakımından incelemeye tabi tutulmuş ve şu sonuçlara ulaşılmıştır:

Ali Ufki kaleme aldığı dini musiki eserlerde ağırlıklı olarak cim harfi ile (ج) sembolize ettiği birinci çizgi do anahtarı kullanmıştır. Yalnızca bir tesbihte bu anahtar üçüncü çizgidedir. Ayrıca tek örneği bulunan tevhid ve ayini şerif’te herhangi bir anahtar işareti kullanılmamıştır. Usul işaretleri ise siyakat adı verilen şifreli bir yazı türü üzerinden dokuz farklı gösterge ile anlam kazanmaktadır. Bu işaretlerin bazıları birden fazla usulü temsil ederken eserin zaman organizasyonu ile gösterge arasında yer yer tutarsızlıklar görülebilmektedir. Ses değiştirmeye yarayan işaret bakımından ise dini nitelikli eserlerde bemol işlevi gören (ب) harfi ile diyez işlevi gören (//) çift eğik çizginin öne çıktığını görüyoruz. Ayrıca günümüzdeki notalama işaretlerinden tekrar/röpriz, puandorg, uzatma ve deyim bağı gibi işaretlerin kullanıldığı sonucuna ulaşmak mümkündür.

Ali Ufki MSS'de oluşturduğu repertuvarı makam fasılları üzerinden tasnif ederken dini nitelikli eserlerin yarıdan fazlasının bağlı olduğu faslın makamıyla uyum göstermediği tespit edilmiştir. Mukayeseli olarak yapılan makam analizi neticesinde dini nitelikli eserlerin Acem, Acemaşiran, Aşiran Buselik, Buselik, Eviç, Hüseyni, Irak, Muhayyer, Neva, Pençgâh, Rast, Sabâ, Segâh, Sünbüle ve Uşşak gibi dönemin önde gelen makamlarıyla temsil edildiği görülmektedir. Bu eserlerin makamsal dağılımında Hüseyni ve Neva makamları öne çıkarken günümüzün dini musiki repertuvarında oldukça sık kullanılan Buselik, Uşşak ve Segâh makamlarının nicel azlığı dikkat çekicidir. Burada Acem, Acemaşiran, Eviç, Irak, Muhayyer, Neva, Pençgâh, Hüseyni, Rast ve Uşşak makamları hem dönemin hem de günümüzün makam anlayışıyla büyük ölçüde örtüşürken Buselik, Aşiran Buselik, Pençgâh, Sabâ, Segâh ve Sünbüle makamları dönemin kaynaklarında yapılan tariflerden hareketle anlam kazanmıştır.

MSS'deki dini nitelikli eserler zaman organizasyonu açısından ele alındığında Düyek, Evfer, Evsat, Semai ve Sofyan usulle öne çıkarken usulü belirlenemeyen eserlerin varlığı azımsanmayacak orandadır. Burada dini eserler en çok Düyek usulü dairesinde yer alırken en az usul Evsat ile temsil edilmektedir. Genel anlamda MSS'deki usul konusundaki tutarsızlık durumunun dini eserlere de yansıması kaçınılmazdır. Örneğin Düyek dairesindeki dini musiki repertuvarındaki zaman organizasyonunda belirli bir standart yoktur. Kimi eserler (2+2)'lik bir düzüm içinde gelişirken kimi repertuvarın dönemin ve günümüzün Düyek tarifine büyük ölçüde uyduğu saptamıştır. Keza Evfer usullü eserler hem dönemin hem de günümüzün Evfer tanımıyla örtüşmezken Semai ve Sofyan usullü eserlerde böyle bir durum söz konusu değildir. Sonuca dair vurgulanması gereken diğer bir husus usulü belirlenemeyen repertuvar bileşenleridir. Burada belirsiz usullerle ilgili iki tip yapı mevcuttur. İlki zaman organizasyonu bakımından tanımlanabilir bir ölçüye uymayan; ikincisi ise tanımlanabilir bir ölçü içinde yer alıp hem döneminin hem de günümüzün belirli usul kalıbıyla örtüşmeyen yapılardır. Ancak Ali Ufki notaya aldığı her iki tipe de giren bazı eserlerin başına usul göstergesi yazmıştır.

MSS'deki dini nitelikli eserlerin form yapılarıyla ilgili sonuçlara bakıldığında altı farklı biçim içinde yer aldıkları ve en fazla biçim yapısının iki bölümden oluştuğu görülebilmektedir. Türler arasında bir karşılaştırma yapıldığında ilahilerin müzikal yapısının tesbihlere nazaran dar kurulumlu ve küçük anlatımlı müziksel ifadeleri barındıran motif ve cümlelerden oluştuğu tespit edilmiş; tevhid ve ayin-i şerif çatısındaki eserlerde de buna benzer bir yapı gözlenmiştir. MSS'deki tesbih eserler din-dışı diğer türleri de kapsayan bir bütünlükte form yapısı olarak farklılığını ve ayrıcalığını ortaya koymaktadır.

MSS'deki dini musiki türlerinin güfte yapısına ilişkin sonuçlara genel olarak bakıldığında önemli bir bölümünün aruz ölçüsü ihtiva ettiğini; nazım şekli bakımından gazel ve murabba formunun öne çıktı̆̆ını buna karşın belirlenemeyen şekil yapılarının nicel olarak varlık gösterdiğini söylemek mümkündür. Her ne kadar dini nitelikli eserlerin güfte yapıları türü belirleyen önemli bir faktör olarak karşımıza çıksa da dönemi itibariyle MSS'de ilahi ve tesbih adlandırmalarının şemsiye bir başlık olarak kullanıldığı varsayılabilir. Nitekim Ali Ufki'nin bilhassa ilahi veya tesbih olarak nitelediği repertuvarın bir bölümü bağlı olduğu tür ile edebi olarak uyum sağlarken bazı eserlerin günümüzün bakış açısından hareketle ramazan ilahisi, na’t, şuğul ve tevşih gibi türlere tekabül ettiğini söylemek mümkündür.

Sonuç olarak MSS'de yer alan dini nitelikli eserler dönemin repertuvarını ortaya koyması bakımından eşsiz bir öneme sahiptir. Burada Ali Ufki kritik bir görev üstlenerek tamamıyla sözlü aktarım geleneğine sahip kadim bir müzik kültürünü ilk kez Avrupa müzik yazısına aktarmak kalmamış saz ve söz eserlerinden dini ve folklorik ögelere kadar Osmanlı/Türk müziğinin önde gelen formlarını tespit ve tetkik etmemize imkân sağlamıştır. Bu açıdan yalnızca dini musiki türlerinin değil MSS'de yer alan diğer tür ve repertuvar bileşenlerinin detaylı bir anatomisinin ortaya koyulması kaçınılmaz bir durum olarak karşımıza çıkmaktadır. 


\section{Kaynakça}

Ayangil, R. (2014). XVII. yüzyılda Türk musikisi. Yeni Türkiye Dergisi, 57, 468-480.

Behar, C. (1990). Ali Ufki ve mezmurlar. Pan Yayıncılık.

Behar, C. (1991). Wojciech Bobowski (Ali Ufki)'nin hayatı ve eserleri hakkında yeni bilgiler. Tarih ve Toplum, $16,17-22$

Behar, C. (2008). Saklı mecmua-Ali Ufki'nin bibliothéque nationale de France' taki [Turc 292] yazmast. Yap1 Kredi Yayınları.

Behar, C. (2015). Osmanlı/Türk musikisinin kısa tarihi. Yap1 Kredi Yayınları.

Behar, C. (2017). Musikiden müziğe Osmanlı/Türk müziği: Gelenek ve modernlik. Yapı Kredi Yayınları.

Cevher, H. (1995). Ali Ufki Bey ve Haza Mecmua-i Saz ü Söz (Transkripsiyon-Inceleme) (Tez No. 42498) [Doktora Tezi, Ege Üniversitesi]. Yüksek Öğretim Kurulu Tez Merkezi.

Cevher, H. (2003). Ali Ufki Hâzâ Mecmuâ-i Sâz ü Söz (Çeviri-yazım-İnceleme). Meta Basım Matbaacılık.

Elçin, Ş. (2000). Mecmûa-i Saz ü Söz. T.C. Kültür Bakanlığı Yayınları.

Karakaya, F. (2010). Ali Ufki Bey. Mas Matbaacılık.

Levendoğlu, N. O. (2002). XIII. yüzyıldan bugüne kadar varlığını sürdüren makamlar ve değişim çizgileri (Tez No. 125814) [Doktora Tezi, Gazi Üniversitesi]. Yüksek Öğretim Kurulu Tez Merkezi.

Oransay, G. (1972). Ali Ufki ve dini Türk musikisi [Yayımlanmamış Doçentlik Tezi]. Ankara Üniversitesi, İlahiyat Fakültesi Kütüphanesi.

Oransay, G. (1976). Santurcu Ali Ufki Beğ konusunda birkaç düzeltme. Türk Folklor Araştırmaları, 325, 223224.

Özden, E. (2020). Osmanlı Maarifinde musiki. Türk Tarih Kurumu Yayınları.

Öztuna, Y. (1987). Türk musikisi teknik ve tarih. Türk Petrol Vakfı Lale Mecmuası Neşriyatı.

Tanrıkorur, C. (2003). Osmanlı dönemi Türk musikisi. Dergâh Yayınları.

Tura, Y. (2001). Kantemiroğlu-Musikiyi harflerle tespit ve icrâ ilminin kitabı (İnceleme-Edvar). Yapı Kredi Yayınlar1.

Uludemir, M. (1985). Mecmua-i Saz ü Söz'de usuller (2). Musiki Mecmuası, 38(410), 15-17.

Uzunçarşı11, İ. H. (1977). Osmanlılar zamanında sarayda musiki hayatı. Belleten, 161, 79-114.

Üngör, E. R. (1987). Gültekin Oransay'ın sekizinci defa tuş oluşu. Musiki Mecmuası, 416, 26-31.

Yerasimos, S. \& Berthier, A. (2012). Albert Bobovious ya da Santuri Ali Ufki Bey'in anıları, Topkapı Sarayında yaşam. (A. Berktay, Çev.). Kitap Yayınevi. 